\title{
PERCERAIAN WARGA GKJW DI KABUPATEN JEMBER: Suatu Analisa Teori Pertukaran Sosial
}

\author{
Imanuel Teguh Harisantoso \\ Fakultas Teologi Universitas Kristen Satya Wacana Salatiga \\ imanuelteguh@yahoo.co.id; https://imanuel-gkjw.blogspot.com
}

\begin{abstract}
The congregation of Gereja Kristen Jawi Wetan (GKJW) in Jember is the subject of the research and an integral part that divorce rates is rising. The teaching of Christian faith is not to be divorced, but in fact divorce occurs. In the 1970s, there were no divorces; however in the 2000s divorce befell in the GKJW Christian family in Jember. The high divorce of church members in Jember in the 2000 s became a challenge to Church service.
\end{abstract}

The data from Jember Regency Population and Civil Registration Office is in line with the divorce happened in GKJW Congregations in Jember. What factors cause divorce in the GKJW Church in all of Jember District? Social supports, administrative requirements, religious background are the main factors causing divorce. While supporting factors, husband and wife accountability, PIL or WIL, family conflicts and communication are the stimulants of divorce.

These are social facts that are intertwined in church service on society context. Institutionally or personally, church servants should prepare themselves and the "tools" of the services being needed, in preparation for possible problems that will occur.

Keywords: church, social, family, divorce

Abstrak: Warga Greja Kristen Jawi Wetan (GKJW) di kabupaten Jember menjadi subjek penelitian dan bagian integral meningkatnya angka perceraian. Ajaran iman umat Kristen adalah tidak boleh bercerai, tetapi kenyataannya perceraian terjadi. Tahun 1970-an tidak ada perceraian, tetapi tahun 2000-an perceraian terjadi dalam keluarga Kristen GKJW di Jember. Tingginya perceraian warga gereja di Jember di tahun 2000an menjadi tantangan pelayanan Gereja.

Data perceraian Dinas Kependudukan dan Catatan Sipil Kabupaten Jember, sebanding lurus dengan perceraian di Jemaat-Jemaat GKJW Kabupaten Jember. Faktor-faktor apakah yang menyebabkan perceraian di Jemaat GKJW se-Kabupaten Jember? Dukungan sosial, persyaratan administrasi, latar belakang agama, menjadi faktor utama penyebab perceraian. Sedang faktor pendukung, tanggung jawab suami isteri, PIL atau WIL, konflik keluarga dan komunikasi menjadi stimulan perceraian.

Inilah fakta sosial yang berkelindan dalam pelayanan gereja dalam konteks bermasyarakat. Semestinya secara institusi ataupun personal pelayan gereja membekali diri dan mempersiapkan "piranti-piranti" pelayanan yang dibutuhkan, sebagai persiapan terhadap kemungkinan persoalan yang akan terjadi.

Kata kunci: gereja, masyarakat, suami-istri, perceraian 
GKJW adalah singkatan dari Gereja Kristen Jawi Wetan (GKJW, 1996) dengan wilayah pelayanan di seputar propinsi Jawa Timur. Sampai dengan tahun 2019 GKJW memiliki 170 Jemaat dewasa. Enam diantaranya berada di Kabupaten Jember: Jemaat Sumberpakem, Jemaat Jember, Jemaat Sidomulyo, Jemaat Sidoreno, Jemaat Sidorejo dan Jemaat Rejoagung.

Sebagian besar warga Jemaat GKJW di Kabupaten Jember berprofesi sebagai petani, dan karenanya mentalitas yang melekat padanya dapat disebut "mental petani (peasant mentality)" (Swalem, 1987, pp. 21-22). Mereka adalah jemaat agraris. Hal ini juga ditunjukan oleh kepemilikan asset Jemaat berupa sawah dan seringkali persoalan seputar pertanian menjadi perhatian sidang-sidang majelis.

Tabel 1. Luas sawah Jemaat-Jemaat GKJW di Kabupaten Jember *)

\begin{tabular}{llc}
\hline No & \multicolumn{1}{c}{ Nama Jemaat } & Luas Sawah \\
\hline (1) & \multicolumn{1}{c}{$(2)$} & $(3)$ \\
1. & Sumberpakem & $1 \mathrm{Ha}$ \\
2. & Sidomulyo & $7-8 \mathrm{Ha}$ \\
3. & Sidoreno & $7,2 \mathrm{Ha}$ \\
4. & Sidorejo & $8,065 \mathrm{Ha}$ \\
5. & Rejoagung & $9,2 \mathrm{Ha}$ \\
6. & Jember & - \\
\hline
\end{tabular}

* Berdasarkan data "Himpunan Laporan dan Informasi Sidang Majelis Daerah Besuki Barat I/2011 di Jemaat Sidorejo, GKJW, 2017".

Seiring dengan perkembangan teknologi dan komunikasi yang semakin tidak terbendung, akhirnya memunculkan "persaingan" nilai agama yang mengajarkan moralitas dengan nilai-nilai sekuler (Nottingham, 1996, 
pp. 64-65) yang menggoda setiap pribadi untuk tidak lagi menunaikan panggilan keagamaannya.

Gaya hidup bebas "melahirkan" seks pra-nikah, tinggal bersama tanpa ikatan perkawinan atau "kumpul kebo" adalah salah satu gejalagejala sosial yang muncul dampak modernisme - globalisasi - pada tatanan mikro kehidupan atau keluarga (Giddens, 2001). Menikah, selingkuh, bercerai dan menikah kembali menjadi sesuatu yang tidak asing bagi masyarakat; menjadi topik bacaan di media cetak; tontonan di media elektronik; buah bibir dan perbincangan masyarakat umum, termasuk didalamnya anggota dan pelayan-pelayan gereja (GKJW, 2010).

Gereja, tentu turut merasakan gejala sosial tersebut: perselingkuhan, perceraian dan perkawinan kembali anggotanya. Tahun 2005 di sebuah Jemaat GKJW di Ambulu Jember, Jawa Timur terdapat dua kasus perselingkuhan. Data dari Dinas Kependudukan dan Catatan Sipil Kabupaten Jember sebagai lembaga yang menerbitkan Akta Perceraian mencatat adanya peningkatan perceraian. Bahkan pada tahun 2009 diputuskan Pengadilan Negeri Jember 2 kasus, tetapi warga GKJW yang bercerai terdapat 4 kasus - 2 kasus hasil dari ketetapan pengadilan dari luar Kabupaten Jember.

Tingginya kasus perceraian menjadi perhatian gereja. Persidangan Majelis Agung (MA) GKJW tahun 2002 menetapkan tema Program Kegiatan Pembangunan (PKP) IV wujudkan keluarga Allah yang menjadi rahmat bagi semua orang (GKJW, 2002). Tema ini menjadi arah dan sa- 
sasaran pelayanan gereja untuk terus mewujudkan kebahagiaan keluarga dan masyarakat.

Tabel 2. Data Perceraian Warga GKJW Kabupaten Jember

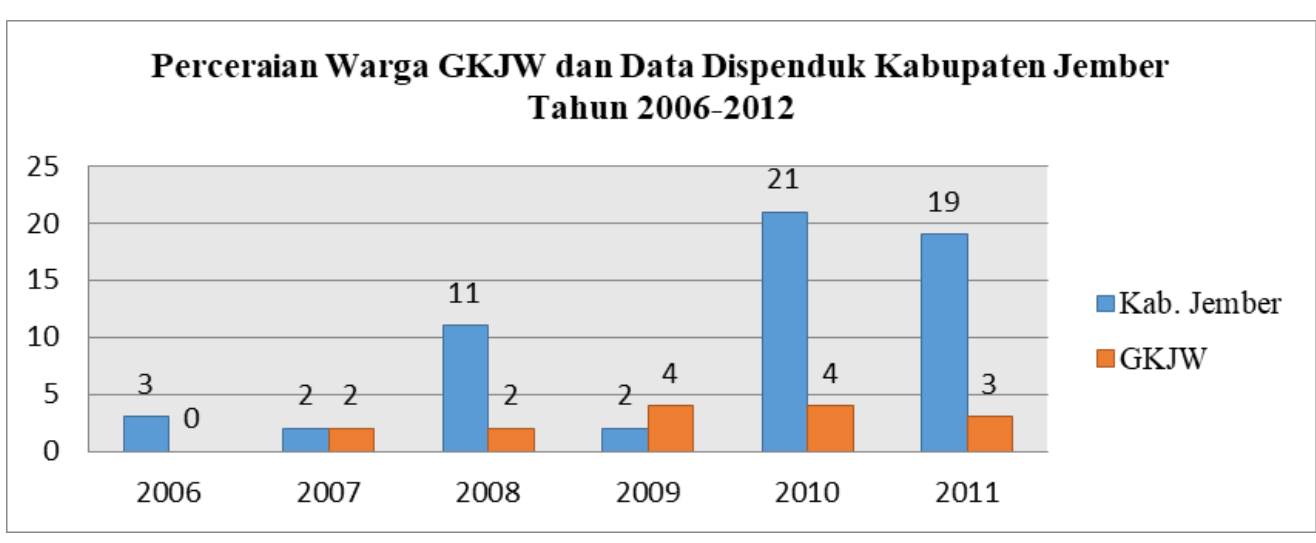

Perhatian terhadap keluarga juga diberikan lembaga internasional Perserikatan Bangsa-Bangsa (PBB). Lembaga ini memutuskan tahun 1994 sebagai Tahun Keluarga Internasional yang patut dirayakan di seluruh dunia. Keluarga secara universal dianggap sebagai sel utama dan sangat vital dari masyarakat. Tidak mungkin suatu masyarakat sehat tanpa keluarga yang sehat pula (Eminyan, 2001). Setiap keluarga mengemban tugas menjadikan perkawinan sebagai ikatan lahir batin untuk tumbuh dan berkembang menjadi pribadi yang dewasa (UndangUndang No 1 tahun 1974 tentang Pernikahan).

Penelitian ini bertujuan untuk mengungkap apa saja faktor-faktor yang menyebabkan perceraian di kalangan warga GKJW.

\section{METODE}

Jenis penelitian. Penelitian ini menggunakan pendekatan kualitatif, sebuah metode berganda dalam fokus, yang melibatkan pendekatan interpretatif dan wajar (naturalistik) terhadap pokok permasalahan yang 
dikajinya. Penelitian kualitatif mencakup semua subjek yang dikaji dan kumpulan berbagai data empiris yang menggambarkan momen rutin dan problematis (Denzin \& Lincoln, 2009).

Keterbukaan dan kepercayaan responden kepada peneliti sangat membantu mengungkap pengalaman kegagalan membina keluarga. Depth interview dengan pertanyaan yang sudah terencana dan terukur akan semakin melengkapi metodologi menggali informasi.

Unit Amatan dan Unit Analisa. Unit amatan dan unit analisa adalah Jemaat-Jemaat GKJW di Kabupaten Jember: Jemaat Sidomulyo, Jemaat Sumberpakem, Jemaat Jember, Jemaat Sidoreno, Jemaat Sidorejo dan Jemaat Rejoagung.

Populasi dan responden. Subjek penelitian adalah warga Jemaat GKJW yang bercerai dengan ketetapan Pengadilan Negeri Jember dengan responden laki-laki dan perempuan. Harapannya, gejala-gejala dilematis yang menyebabkan perceraian dapat diungkapkan secara berimbang baik oleh laki-laki maupun perempuan. Sekaligus mendapatkan gambaran sosiologis-psikologis terhadap pokok yang diteliti.

Tehnik pengumpulan data. Wawancara mendalam dengan pertanyaan yang terstruktur dan studi kasus akan menjadi tool dalam pengumpulan data penenlitian ini. Wawancara dilakukan terhadap responden atau pelaku perceraian dan pendeta Jemaat serta tokoh masyarakat setempat. Selanjutnya, untuk melengkapi data penelitian juga dilakukan observasi (Denzin \& Lincoln, 2009). 
Guna mendukung hasil kajian yang komprehensif, juga dilakukan observasi terhadap saksi perkawinan dan saksi dalam sidang pengadilan putusan perceraian sebagai subjek penelitian.

\section{Teori Pertukaran Sosial}

Pertukaran berasal dari kata dasar tukar, sedangkan kata kerja bertukar memiliki beberapa pengertian: 1) Memperoleh sesuatu dengan memberikan sesuatu atau bergantian memberi sesuatu dengan sesuatu yang lain; 2) Berubah dari atau menjadi yang lain; 3) Berpindah dari kendaraan yang satu ke kendaraan yang lain. Dalam melakukan aktivitas bertukar kedua pihak memiliki maksud dan tujuan yang sepaham, meskipun berlainan cara melaksanakannya. Sedangkan arti kata pertukaran itu sendiri menunjuk pada tindakan dan perbuatan bertukar atau mempertukarkan sesuatu sebagaimana yang dimaksudkan dalam pertukaran tersebut (KBBI, 2016); (Hornby, 2010).

Apa yang dipertukarkan: diberikan atau diterima? The New Oxford Illustrated Dictionary (Hornby, 2010) mencatat sesuatu yang dipertukarkan biasanya berupa uang, catatan-catatan penting, deposito bank, kata-kata, pandangan-pandangan (glances) tentang sesuatu hal. Hal yang dipertukarkan pada dasarnya memiliki nilai yang lebih kurang sama.

Pertukaran dalam pengertian konseptualisasi interaksi sosial memiliki sejarah yang panjang dalam bidang antropologi dan sosiologi. Teori pertukaran, demikian konseptualisasi tersebut. Pendekatan tersebut dapat ditemukan dalam karya J. Rex dan G.C. Homans (Rex \& 
Homans, 2007) dan Peter M. Blau dan rekan-rekannya (Blau, 2002); (Collins \& Blau, 2006); (Bierstedt \& Blau, 2006); Mereka mengikuti perspektif hedonisme dan utilitarianisme yang lebih mengutamakan kepuasan-kepuasan pribadi. Berangkat dari asumsi bahwa penghargaan hanya dapat diperoleh dari interaksi sosial diantara manusia yang satu dengan yang lain. Teori pertukaran memiliki keserupaan antara interaksi sosial dan transaksi ekonomi di pasar, mereka berharap akan mendapatkan keuntungan dari hubungan tersebut (Dictionary Sociology, 2006, pp. 139-140).

Hubungan sosial yang terjadi dalam masyarakat, mempunyai perilaku yang saling mempengaruhi, didalamnya terdapat unsur ganjaran (reward) atau penghargaan sosial, pengorbanan (cost) dan keuntungan (profit). Analisa hubungan sosial menurut cost and reward inilah ciri khas teori pertukaran (Truzzi \& Turner, 2006).

\section{HASIL}

Table 3. Data Responden

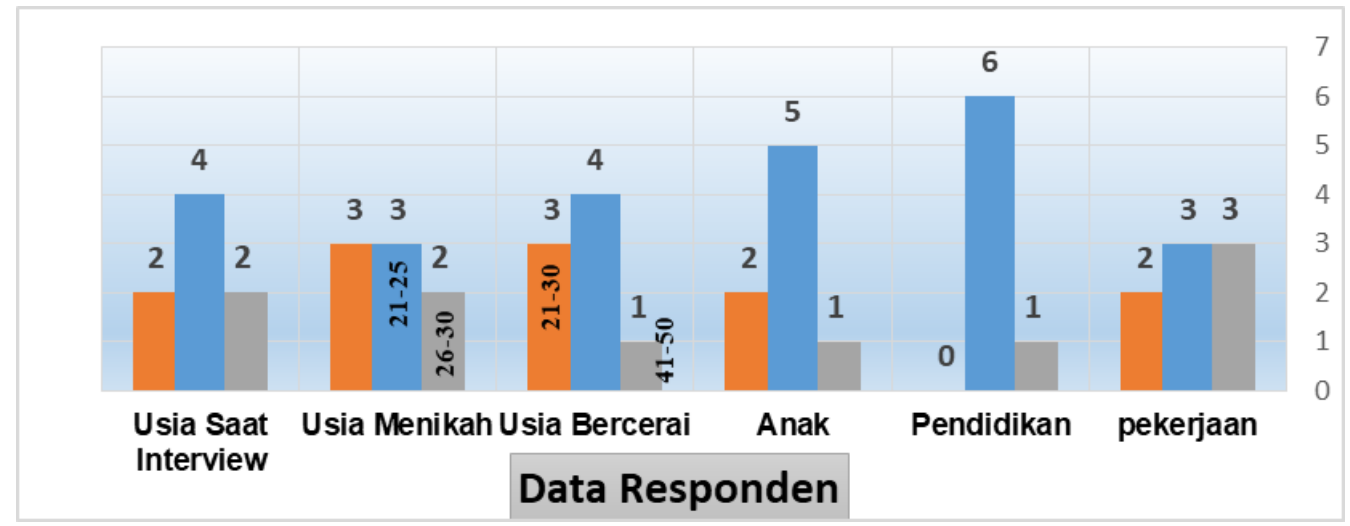




\section{Kehidupan Perkawinan Sebelum Bercerai}

Sebagian besar responden hidup bersama sebagai suami-isteri selama 1-10 tahun, meskipun ada juga yang dapat mempertahankan perkawinan mereka pada usia 11-20 tahun (Data kutipan akta perceraian yang diterbitkan oleh Dinas Kependudukan dan Catatan Sipil Kabupaten Jember). Tetapi kenyataannya (de facto) sebelum pasangan suami istri bercerai mereka telah berpisah. Yang lain menunjukan hanya hidup bersama selama tiga (3) bulan setelah perkawinan, selebihnya berpisah sampai putusan pengadilan memvonis perceraiannya.

\section{Suasana Perkawinan}

Suasana setelah perkawinan

Pada mulanya sangat menyenangkan, selalu bersama, disertai toleransi yang tinggi dan gairah seksual yang menggebu. Konflik atau pertengkaran dianggap hal yang wajar dalam kehidupan suami istri.

\section{Suasana perkawinan sebelum perceraian}

Tidak ada lagi keharmonisan dan rasa cinta lagi. Pertengkaran sering terjadi dan bahkan salah satu bisa pergi bekerja ke luar negeri tanpa pamit.

Suasana hati setelah perceraian

"Bahagia"; "Jauh lebih baik berpisah dengan pasangan"; "Sekarang lebih tenang"; "Sekarang lebih damai" adalah gambaran suasana hati setelah perceraian. Responden merasa seolah merasakan kebebasan yang luar biasa dari tekanan batin yang selama ini menyiksa. 


\section{Faktor-Faktor Penyebab Perceraian}

\section{Faktor-faktor Utama}

Disebut faktor utama karena hal-hal inilah yang menjadi penyebab pokok menguatnya keberanian individu-individu dan keluarga memutuskan untuk bercerai dengan pasangannya, meskipun keputusan ini menimbulkan resiko sosial yang cukup berat, misal: diasingkan dari pergaulan masyarakat atau terkena siasat gereja.

Dukungan sosial

“Apakah di sekitar tempat tinggal anda terjadi kasus perselingkuhan dan atau perceraian?" Semua responden menjawab, "Ya". Jawaban tersebut sejalan dengan observasi yang penulis lakukan. Berdasar pembicaraan dengan tokoh masyarakat, tokoh gereja, tetangga, bahkan orang tua responden, mereka menyatakan adanya kasus-kasus perselingkuhan di sekitar tempat tinggal.

"Keuntungan" tinggal di lingkungan masyarakat dengan tingkat perselingkuhan dan atau perceraian tinggi adalah mendapatkan informasi tentang perceraian itu sendiri dan bagaimana pengurusannya di pengadilan. Responden seolah mendapatkan "dukungan moral" atas persoalan perceraian yang dialaminya. Selain itu, dorongan keluarga (Goode, 1983, pp. 148-150). menjadi kekuatan tersendiri untuk mengambil keputusan bercerai terlebih bagi mereka yang memiliki status sosial-ekonomi tinggi (the higher socio-economic) (Rodgers \& Stroup, 2006). 
Tuntutan administrasi kependudukan

Gugatan perceraian yang dilayangkan oleh responden didorong, terutama oleh tuntutan adminitrasi apabila yang bersangkutan menikah kembali harus memiliki surat keputusan pengadilan perihal status diri, kawin atau duda/janda. Artinya, apabila negara tidak mensyaratkan seseorang yang sudah menikah dan mengalami kegagalan rumah tangga -bercerai - harus mempunyai "surat cerai" untuk dapat menikah kembali, mereka tidak akan pernah mengajukan gugatan cerai ke pengadilan. Jadi gugatan perceraian hanyalah sebuah pilihan rasional (rational choice) yang dilakukan untuk mencapai sebuah tujuan dan tindakan tertentu (Ritzer dan Goodman, 2009, p. 480).

Konversi agama yang "belum selesai"

Perkawinan yang melibatkan salah satu pasangan harus mengalami konversi agama adalah sebuah pergumulan tersendiri. Di satu sisi seolah -olah tidak terjadi masalah dalam keluarga, tetapi di sisi lain, hal ini menjadi permasalahan keyakinan yang belum terselesaikan. Masalah liturgis (mungkin) bisa diterima dengan baik, tetapi permasalahan keyakinan, pemahaman termasuk yang berkaitan dengan keluarga dan topik tulisan ini, apakah mereka menerima dan mengimani dengan baik? Hasil observasi dan wawancara secara mendalam menunjukan perbedaan latar belakang agama menjadi permasalahan tersendiri dalam membina keutuhan rumah tangga. 
"Menikah paksa"

Seks pra-nikah, hamil terlebih dahulu dan menyelamatkan "gengsi” keluarga, rerata yang mengawali perkawinan responden. Saling cinta semasa pacaran? Ya, tetapi tidak pernah membayangkan bahwa perkawinan akan datang sangat cepat dan "merenggut kebahagiaan" masa muda. Dalam wawancara responden mengaku awalnya sebenarnya belum siap menikah, berharap bisa menolak perkawinan, tetapi tidaklah mungkin. Jadi ya... "menikah paksa".

\section{Faktor-faktor Pendukung}

Faktor pendukung adalah pemicu timbulnya permasalahan keluarga yang pada akhirnya menyebabkan perceraian.

Tanggung jawab

Sebelum mengajukan gugatan cerai ke pengadilan, rerata responden "sudah berpisah" dengan pasangannya. Perpisahan ini membawa konsekuensi lalainya tanggung jawab yang harus mereka dipenuhi. Suami sudah tidak menafkahi istri, baik kebutuhan jasmani maupun kebutuhan rohani, demikian juga sebaliknya istri tidak lagi memainkan peran sebagaimana mestinya.

Hadirnya "orang ketiga"

Perselingkuhan merupakan alasan yang kuat untuk mengajukan gugatan cerai. Adanya pihak ketiga dalam rumah tangga mengakibatkan pasangan sering meninggalkan rumah dan lupa akan kewajibannya sebagai suami istri. 


\section{Faktor konflik rumah tangga}

Semua responden mengaku bahwa pada mulanya kehidupan mereka rukun, bahagia seperti layaknya kehidupan keluarga yang harmonis. Namun semuanya berubah ketika pertengkaran-pertengkaran kecil tidak segera diselesaikan, sehingga akhirnya menjadi malapetaka yang besar. "Setelah 9 (sembilan) tahun perkawinan antara Penggugat dan Tergugat mulai terjadi pertengkaran yang semakin lama semakin menjadijadi” (Pengadilan Negeri Jember, 2007a, pp. 1-2); (Pengadilan Negeri Jember, 2007b, p. 2) dan berakhir dengan keputusan cerai oleh pengadilan.

Komunikasi

Masalah komunikasi menjadi alasan serius dalam persoalan rumah tangga (Pengadilan Negeri Jember, 2007b, p. 2). Seringkali komunikasi digantikan dengan alat hiburan (handphone) yang menyita perhatian keluarga. Dikarenakan tidak adanya waktu khusus keluarga, mereka menghabiskan waktu dengan alat hiburan, sehingga dampak dari semua ini semakin memunculkan kesalahpahaman keluarga. Komunikasi yang dibangun tidak lagi melibatkan kemauan dan perasaan sepenuh hati, tetapi terjadi tanpa hati dan lebih bersifat formalitas.

\section{PEMBAHASAN}

\section{Proses Menuju Perceraian}

Proses menuju perceraian yang dialami oleh warga GKJW di Kabupaten Jember diawali dengan mandegnya proses take and give pasangan suami istri. Tidak dicapainya penghargaan suami i stri dalam 
bentuk ganjaran intrinsik seperti: kasih sayang dan perhatian, dan ganjaran ekstrinsik seperti: uang-kebutuhan ekonomi, barang-barang kebutuhan rumah tangga dan jasa. Akibatnya hubungan duaan ini tidak memuaskan masing-masing pihak (Gulardi, 1999).

Mandegnya proses pertukaran suami istri sebagai kelompok dyad memunculkan konflik oleh rasa permusuhan dan kebencian diantara kedua belah pihak. Dalam proposisi stimulus Homans dan juga prinsip timbal balik Blau menyebutkan, semakin banyak orang bertukar hadiah satu sama lain, semakin besar pula kemungkinan pertukaran timbal balik selanjutnya terjadi diantara mereka; dan semakin hubungan timbal balik ini tidak dilakukan, semakin menerima sanksi negatif dalam norma pertukaran sosial (Bierstedt \& Blau, 2006); (Truzzi \& Turner, 2006). Situasi demikian semakin sulit, karena semakin menghilangnya pujian serta penghargaan yang diberikan kepada pasangan. Padahal, pujian dan penghargaan, cinta kasih yang diberikan kepada pasangan suami istri merupakan dukungan emosional yang sangat diperlukan dalam suatu perkawinan. Hal-hal tersebut diatas mengakibatkan hubungan suami istri semakin jauh dan memburuk.

Untuk mempermudah penjelasan suasana perkawinan dalam proses bergerak menuju perpisahan karena perceraian, penulis menggambarkan dalam fase-fase sebagai berikut (Rodgers \& Stroup, 2006):

- $\quad$ Respon kasih sayang yang kurang, akibatnya pasangan mencari kompensasi untuk kekurangan hubungan dalam beberapa kasus. 
- $\quad$ Kemungkinan kata "perceraian" mulai disebutkan.

- Munculnya keprihatinan sebelum diketahui oleh banyak orang. Cerita solidaritas ini sangat penting sebagai alasan untuk menjaga diri. Sekali saja berantakan, maka perkawinan tidak dapat dipertahankan lagi.

- Keputusan perceraian dibuat, biasanya setelah perseteruan yang sangat panjang (long discussion), meskipun beberapa kali keputusan dibuat tanpa pemikiran ke masa lampau.

- $\quad$ Sebuah krisis yang diperparah dengan perpisahan. Memutus hubungan adalah pengalaman traumatik yang paling baik, meskipun hal ini dirasa menjadi jalan satu-satunya.

- Keputusan perceraian menjadi kenyataan. Bisa jadi hal ini melalui periode panjang setelah penundaan dan perpisahan. Pemikiran ini menjadi akhir dari kasus yang ada, prosedur hukum (legal procedure) dibutuhkan sebelum tahap akhir adaptasi baru dimulai.

- Menata hati dan pikiran, rekonstruksi menutup kasus. Mulai memasuki hubungan sosial dengan mitra baru dan memiliki kelonggaran penuh.

\section{Dukungan Sosial dan Perceraian}

Pada tahun 1970-an perceraian di kampung-kampung Kristen hampir tidak ada: Sidomulyo (1972 - satu kasus) dan Rejoagung (1975 - satu kasus). Tetapi memasuki tahun 2000-an kasus demi kasus perceraian mulai marak dalam masyarakat. 
Penulis melihat dukungan sosial mempunyai peran yang sangat signifikan mempengaruhi warga gereja dalam mengambil keputusan. Dukungan sosial kepada orang lain sangat membantu, melegitimasi dan sekaligus mengesahkan "pembenaran" keputusan dan tindakan seseorang untuk melakukan perceraian. Bukan masalah benar atau salah, bukan masalah dogma atau "ajaran gereja” (Stott, 1996, p. 394) karena meskipun perceraian dianggap sebagai yang salah, melanggar norma kekristenan dan Alkitab, tetapi tetap sulit untuk tidak dilakukan.

Kuatnya dorongan dan dukungan dari lingkungan sosial, baik lingkungan sosial yang paling dekat dengan responden maupun lingkungan sosial menjadi motivasi responden untuk bercerai.

\section{Hubungan Pertukaran Sosial dan Perceraian}

Suami istri sepakat, bahwa tujuan perkawinan adalah kesejahteraan hidup keluarga. Mereka mempunyai tanggungjawab yang sama dalam prinsip reciprocity di tengah interaksi sosialnya. Interaksi sosial menjadi sumber kebahagiaan, baik berhubungan dengan hartauang, cinta maupun kekuasaan. Hubungan itu mendatangkan kepuasan yang timbul dari perilaku pasangan: saling memperhatikan, menghormati, menghargai, mencintai, berbuat sesuatu bagi sesamanya dan saling memberikan dukungan sosial. Apabila tidak, maka pasangan pertukarannya, suami dan atau istri akan mengalami kesedihan. "Cinta" dan "kekuasaan" akan kehilangan makna, tanpa adanya pihak lain untuk dicintai ataupun dikuasai. Artinya, secara umum penderitaan dan kebahagiaan manusia ditentukan oleh tindakan dan perilaku orang lain. 
Kebahagian dan ketidakbahagiaan; keutuhan hidup keluarga dan perpisahan suami istri ditentukan oleh istri dan atau suami itu sendiri.

Analisa pertukaran sosial terhadap kasus perceraian yang terjadi, melihat beberapa alasan pertukaran yang terjadi mendapat reward kepuasan atau tidak bagi pasangan. Pertama, kepuasan pasangan suami istri terhadap imbalan sangat berkaitan dengan harapan dan kenyataan pertukaran yang sedang berlangsung. Karena pertukaran juga harus memperhatikan prinsip-prinsip justice dan reciprocity, maka pasangan pertukaran ini mulai menghitung-hitung "keuntungan ekonomis" dari hubungan pertukaran yang dibangun. Rasa puas akan timbul, ketika kedua-belah pihak sama-sama mendapatkan keuntungan dari pertukaran tersebut, tetapi sebaliknya ketidakpuasan akan datang, ketika salah satu pihak, suami atau istri merasa lebih banyak berkorban dibandingkan pasangannya.

Kedua, kepuasan dan atau ketidak-puasan suami istri disebabkan karena pasangan pertukaran membandingkan dengan orang lain, misal mantan pacar, tetangga atau saudaranya. Hasil penelitian menunjukan ketidakpuasan suami atau istri dalam pertukaran juga disebabkan oleh "kecemburuan" terhadap pihak lain, karena mereka merasa pasangan pertukarannya bersikap tidak adil dan lebih memperhatikan orang lain, misalnya orang tua, saudara, dan atau "pasangan gelapnya". Mulai membandingkan rasio input-output pasangannya dengan orang lain; pasangan dipandang tidak lebih baik dari saudara, teman, tetangga dan mantan pacar. 
Ketiga, suami istri sebagai pasangan pertukaran sering salah mengerti (misperceive) terhadap norma dan nilai pertukaran yang ada. Salah persepsi ini seringkali menyebabkan ketidakpuasan suami istri dalam transaksi pertukaran, sehingga sering terjadi konflik.

Terakhir, puas atau tidaknya suami istri dalam hubungan pertukaran disebabkan oleh karena kombinasi variasi imbalan intrinsik dan ekstrinsik. Kebahagiaan atau ketidak-bahagiaan hubungan suami istri sangat bergantung kepada yang bersangkutan, bagaimana pasangan mengeksplorasi sumber daya yang ada: berasal dari hubungan itu sendiri, misal cinta, perhatian, dsb, maupun sumber daya eksternal, harta, kekayaan material dsb.

Evektifitas dan variasi hubungan yang bersifat intrinsik dan ekstrinsik dalam keunikan hubungan suami istri dapat menjamin kelanggengan pertukaran yang ada.

\section{KESIMPULAN}

Sama seperti perkawinan, perceraian juga merupakan sebuah proses yang didalamnya menyangkut banyak aspek: emosi, sosial, ekonomi dan keyakinan. Dalam perkawinan suami isteri saling bertukar "hadiah": kasih sayang, perhatian, ikatan emosional (intrinsik), maupun materi, uang, harta dan lain sebagainya (ekstrinsik), yang membuat hubungan pertukaran diantara mereka menjadi unik dan tertutup bagi pihak lain. Sebaliknya, perceraian memutus hubungan pertukaran yang terjadi selama ini. Perceraian dipandang sebagai sesuatu yang mendatangkan oposisi dan konflik, kerugian yang harus diputuskan. 
Perceraian bukanlah semata-mata gagalnya transaksi pertukaran suami isteri, tetapi merupakan gejala sosial menurut konteks sosialnya.

Akhirnya, sebagai sumbangan pemikiran dan refleksi atas penelitian ini akan sangat penting untuk memperhatikan: Pertama, perlunya dipersiapkan tim pendamping pelayanan keluarga. Meningkatnya perceraian warga geraja, salah satunya disebabkan oleh tidak adanya tim pendamping pelayanan keluarga dengan kemampuan dan ketrampilan (skill) memadai.

Kedua, Pelayanan keluarga inklusi. Mengingat ragam dan kompleksnya persoalan keluarga, maka penulis menyusun rumusan pelayanan keluarga inklusi adalah sebuah pelayanan dengan metode dan materi khusus untuk keluarga-keluarga yang memiliki kelebihan di bidang lain, tetapi tertinggal dengan yang lain di bidang yang lainnya. Misal: suami atau istri dalam sebuah rumah tangga yang aktif dalam kegiatan dan pelayanan gerejawi (kognitif dan motorik), tetapi secara ekonomi ia kurang beruntung. Artinya, pelayanan keluarga perlu memperhatikan siatuasi dan kondisinya (context), dan bersifat kasuistik.

Akhirnya, bagi kepentingan pengembangan pemahaman dan pelayanan terhadap keluarga, gereja, maupun oleh lembaga pendidikan perlu dilakukan penelitian lanjutan tentang topik-topik yang berkaitan dengan persoalan keluarga, misal hubungan perceraian dengan tradisi atau culture, psikologi perkawinan dan perceraian, hubungan perceraian dengan perekonomian keluarga dan lain sebagainya. Semoga. 


\section{DAFTAR PUSTAKA}

Bierstedt, R., \& Blau, P. M. (2006). Exchange and Power in Social Life. In American Sociological Review (Vol. 30). https:/l doi.org/10.2307/2091154

Blau, P. M. (2002). A Macrosociological Theory of Social Structure. American Journal of Sociology, 83(1), 26-54. https:/l doi.org/10.1086/226505

Collins, R., \& Blau, P. M. (2006). Inequality and Heterogeneity: A Primitive Theory of Social Structure. In Social Forces (Vol. 58). https://doi.org/10.2307/2577612

Denzin, N. K., \& Lincoln, Y. S. (2009). Handbook of Qualitative Research. Yogyakarta: Pustaka Pelajar.

Dictionary Sociology. (2006). London: Penguin Reference.

Eminyan, M. (2001). Teologi Keluarga. Yogyakarta: Kanisius.

Giddens, A. (2001). Runway World: bagaimana globalisasi merombak kehidupan kita. Jakarta: PT Gramedia Pustaka Utama.

GKJW. Tata dan Pranata GKJW. , (1996).

GKJW. Akta dan Catatan Sidang Majelis Agung GKJW. , (2002).

GKJW. (2010). Materi Sidang Majelis Jemaat GKJW Sidomulyo tanggal 24 Februari 2010 dan Rapat PHMJ tanggal 11 Agustus 2010.

GKJW. (2011). Himpunan Laporan dan Informasi Sidang Majelis Daerah Besuki Barat I/2011 di Jemaat Sidorejo.

Goode, W. J. (1983). Sosiologi Keluarga. Jakarta: Bina Aksara.

Gulardi, S. T. (1999). Perubahan Nilai di Kalangan Wanita Bercerai. In T. O. Ihromi (Ed.), Bunga Rampai Sosiologi Keluarga. Jakarta: Yayasan Obor Indonesia.

Hornby, A. S. (2010). Oxford Advanced Learner's Dictionary ( International Student's Edition ). In Oxford University Press.

KBBI. (2016). KBBI - Kamus Besar Bahasa Indonesia. In Kbbi.Kemdikbud.Go.ld (3rd ed.). Jakarta: Balai Pustaka.

Nottingham, E. K. (1996). Agama dan Masyarakat: Suatu Pengantar Sosiologi Agama. Jakarta: RajaGrafindo Persada. 
Pengadilan Negeri Jember. Turunan Putusan Perkara Perdata Nomor 100/Pdt.G/2007/PN.Jr. , (2007).

Pengadilan Negeri Jember. Turunan Putusan Perkara Perdata Nomor 35/ Pdt.G/2007/PN.Jr. , (2007).

Rex, J., \& Homans, G. C. (2007). Social Behaviour, Its Elementary Forms. The British Journal of Sociology. https:/l doi.org/10.2307/587952

Rodgers, R. H., \& Stroup, A. L. (2006). Marriage and Family: A Developmental Approach. In Journal of Marriage and the Family (Vol. 29). https://doi.org/10.2307/349618

Stott, J. (1996). Isu-Isu Global Menantang Kepemimpinan Kristian (3rd ed.). Jakarta: Yayasan Komunikasi Bina Kasih/OMF.

Swalem, I. G. K. (1987). Pembangunan Desa. Buleleng: Kantor Pembangunan Desa Kabupaten Buleleng.

Truzzi, M., \& Turner, J. H. (2006). The Structure of Sociological Theory. In Social Forces (6th ed., Vol. 54). https://doi.org/10.2307/2576657 